\title{
Legal Protection of Special Facilities for Woman Labors in Socio-Legal Perspectives
}

\author{
M. Sayyid Abyan ${ }^{1 *}$, Dyah Wijaningsih ${ }^{2}$, Budiyanto ${ }^{3}$ \\ \{sayyid1297@gmail.com $\left.{ }^{1}\right\}$ \{ dyah_wijaningsih@live.undip.ac.id ${ }^{2}$ budiyanto@live.undip.ac.id ${ }^{3}$ \}
}

Fakultas Hukum, Universitas Diponegoro, Jl. Prof. H. Soedarto, S.H., Semarang, Indonesia $50275^{1}$

\begin{abstract}
Nowadays, the phenomenon of women participating in improving family welfare by working is considered a common things. However, women's labor still tend to be in the most difficult position due to Patriarchal culture that still exists in Indonesia. The Law of The Republic of Indonesia Number 13 of 2003 on Employment already regulates the fulfillment of women's labor rights. One of the points is the special facility rights along with the sanctions. The number of worker's organizations that fully accommodate the special rights are 152 out of 3041. This research used the Socio-Legal Research method where it combines two types of data, primary data and the secondary data. This research focused to look the effectivity of the law enforcement in the community with descriptive analytics research specification. In this research, it was found that the company is not optimally provides the special facility rights of the woman labor at Alfamart Kampung Rambutan. There are many things that are not accordance with the law that should have been provided to the woman labor in terms of surveillance, fulfillment of the rights, and legal protection.
\end{abstract}

Keywords: Implementation, Special Facility Rights, Woman Labor.

\section{Introduction}

Nowadays, the phenomenon of women participating in improving family welfare by working is considered normal, [1] However, women's labors still tend to be in the most difficult position due to Patriarchal culture.[2] Even though various gender equality issues and movements, equal rights and freedom are getting better throughout the world, this does not undermine stereotypical thinking that considers men to be superior to women in many ways. at work, this has an impact on the occurrence of domination and discrimination by male workers in which are prioritized in getting jobs and are chosen to occupy strategic positions compared to women.[1] The domination and discrimination make women's position more difficult because of the increasingly closed possibility of women to work, get a decent life and develop themselves, especially in the career world.

This also has implications for the fulfillment of special rights for female workers even if it has been clearly stipulated in the Law and other regulations. Even with sanctions, there are still many companies that pretend to be unable or unwilling to fulfill these rights. [3] Based on data from the Ministry of Health, there are 3041 companies in Indonesia, of which only 152 companies fully accommodate the full privileged rights of women workers. Even though the number of companies aware of the rights, these facilities continues to increase from previous years. However, this does not mean that 2,889 companies do not fulfill the full rights of 
women workers, but the rights are not fully granted by these companies, [4] still accommodating some is considered contrary to Article 76 of Law Number 13 of 2003 concerning manpower which also violates the basic rights contained in the 1945 Constitution of the Republic of Indonesia.

Alfamart which is a well-known minimarket in Indonesia. Alfamart in running shop productivity uses a shift system where there is a day shift and there is a night shift. Because they use night shifts and employ women, Alfamart requires to accommodate the privilege of special facilities for female workers. However, in fact, (Das Sein) many things are not in accordance with what is aspired by the Law (Das Solen) both in terms of supervision, fulfillment and even legal protection related to the rights of special facilities for female workers who make arrangements about it seem not yet optimal implementation.

Based on the description above, the problem formulation that can be compiled consists of:

1. What is the arrangement of special facility rights according to Law number 13 of 2003 ?

2. How is the implementation of the legal protection arrangements for special facilities for female workers at Alfamart Kampung Rambutan?

\section{Method}

The approach used is Socio-Legal research which is a combination of dogmatic legal research methods and empirical legal research methods. In the legal research method approach Socio-Legal research, there are 2 (two) aspects of research.[5] First, the legal research aspect is analyzing the problem from the point of view/according to the provisions of the law/legislation seen as (das sollen). In discussing issues in the legal protection of the special facilities rights of women workers, it uses legal materials both primary legal materials such as the 1945 Constitution of the Republic of Indonesia, Law No. 13 of 2003 concerning Manpower, [6] and so on, as well as secondary legal materials obtained from literature studies such as books, journals, and other literature relating to the legal protection of the special facilities for women workers. Furthermore, by using a socio research approach that looks at "the reality that occurs in the community" (das sein), because in research on the legal protection of the special facilities for women laborers social theories and empirical methods that use primary data such as interviews are used. obtained from the field.[7]

The research specifications used in this research are Analytical Descriptive. it is a problem solving process which is investigated through data obtained and arranged systematically to describe the paradox in the evidence found in the field and then analyzed based on the concepts and theories proposed. This process is carried out to strengthen the analysis of the evidence found in the field so that inductive conclusions can be considered valid.[5]

\section{Data Collection}

The data used in this study consisted of primary data and secondary data. Primary Data is data obtained from the field such as interviews. Secondary data is data obtained through literature study.

Legal materials taken by researchers consisted of primary legal materials: 
1. The 1945 Constitution of the Republic of Indonesia

2. Law Number 13 of 2003 concerning Manpower.

3. Law Number 39 of 1999 concerning Human Rights

4. Law Number 36 of 2009 concerning Health

5. International Labor Organization (ILO) Convention Number 183 of 2000

6. Presidential Decree No. 83 of 1998 concerning Freedom of Association and Protection of the Right to Organize.

7. Decree of the Minister of Manpower and Transmigration No. KEP102/MEN/VI/2004 of 2004 concerning Overtime Working Hours and Overtime Work Wages.

8. Circular of the Minister of Manpower of the Republic of Indonesia Number SE07/Men/1990 of 1990 concerning Grouping of Wage Components and Non-Wage Income.

Secondary legal materials consisting of:

1. Book

2. Journal

3. Dissertation, Thesis, and Legal Thesis

4. Papers

Tertiary Legal Materials consist of:

1. Large Indonesian Dictionary

2. Popular Scientific Dictionary

3. Legal Dictionary

4. Legal Encyclopedia

5. Internet

\section{Results and Discussion}

\subsection{The form of legal protection for the special rights of women workers in Law number 13 of 2003 concerning manpower}

All workers have the right to get the same treatments but every woman has special rights. It is related to human rights that must be recognized and protected by all people as well as the law. The granting of special rights for women is because women are included in the category of vulnerable groups so that they deserve special treatments in the regulation on guaranteeing the protection of human rights. Generally, the granting of women's rights is the same as granting other rights as mentioned in the articles of the Law on Human Rights but for the reasons stated above, it is deemed necessary to reaffirm. The principles that underlie the granting of women's rights include the right to a gender perspective and the principle of antidiscrimination. This means that every woman has the same rights as men in all fields of education, politics, law, citizenship, employment including rights in marriage and their obligations.

When talking about women's rights in the field of labor, the special rights mentioned above must be given to women workers not only when women work but it also includes spaces before women get a job, when doing work, the phase after work or the phase is not 
working again. In the phase before having a job every woman has rights. Among these rights are the right to be given the same opportunities as men to get jobs that are within their means. This right requires companies to accept prospective workers by actually selecting the job applicants fairly without giving more opportunities to one specific gender.

During the work time, a woman worker has rights that must be fulfilled including the right to receive wages in accordance with her work, the right to get safe and healthy workplace conditions, the right to have the opportunity to be able to increase her work higher, and also includes the right to get facilities and training to improve the quality of their work.

After a job or phase where a female worker quits her job and does not work anymore, there are times when women decide to quit and leave their work for certain reasons. When that happens, a woman has the right to receive severance pay fairly in accordance with the performance and quality of the work she has done. The granting of these rights is because both in Indonesia and in other countries, the presence of women workers is felt to always get unfair treatment so that it requires legal protection and affirmation of Human Rights especially Human Rights as a woman. Human rights today are considered a modern political ethic with the core idea that there are moral demands regarding how humans are required to treat humans, so that this is because it is very strong to protect people and groups who are weak against their powerful authority because of their position, age, status and others.

The discussion on the protection of the special facilities for women workers is within the right scope with the aim of protecting the security and safety of women workers. The rights that are required to receive legal protection include:

1. Menstrual Leave Rights. Menstrual leave is regulated in Law No. 13 of 2003 article 81. Female workers who are menstruating are permitted not to work on the first and second day. This leave is granted only if it is attached with a letter of advice from a doctor.

2. Pregnant Leave Rights. For pregnant women workers, 1.5 months length is a given time to leave before giving birth and 1.5 months after. This is regulated in Law no. 13 of 2003 article 82 . For filing this leave, female workers must notify the management of the company at least 1.5 months before the estimated birth. Similarly, after the birth of a child, it should be reported to the company no later than 7 days by attaching proof of birth or birth certificate.

3. The Right to Social Security. Law No. 3 of 1992 concerning Workers' Social Security and PP no. 14 of 1993 concerning the Implementation of the Workers' Social Security Program regulates the obligations of companies that have more than ten workers or pay at least Rp. 1 million to include all of its workforce in the BPJS program.

4. The Right to Breastfeed. In article 83 of Law no. 13 of 2003, it is stated that female workers who are still breastfeeding, are welcome to breastfeed during working hours. Article 10 ILO convention no. 183 of 2000 regulates the time duration and reduction of working hours given to nursing mothers, at least one or more breaks during working hours. In this regard, it is recommended that companies have their own appropriate breastfeeding space.

5. Miscarriage Rights. For women workers who have miscarriages, they also get the same rights as maternity leave for 1.5 months or in accordance with doctor's advice. To prove this, women workers attach a doctor or midwife certificate.

6. Prohibited Rights Affected from layoffs. Minister of Manpower Regulation no. Permen 03/Men/1989 regulates the prohibition of layoffs on female workers by reason of marriage, pregnancy and childbirth. This is based on the protection that these three things are his nature, dignity and dignity as a woman. 
7. Rights are given Special Facilities. Not that female workers are privileged. But more to the protection of security and health. Regulation of Law no. 13 of 2003 article 76 states that female workers who work between 23:00 o'clock. 07.00 has the right to get nutritious food and drinks as well as maintained its decency and safety while at work. Regarding security, employers are required to provide pick-up and drop-off for female workers between 11:00 p.m. 05:00.

Of the seven rights above, the sad condition in Indonesia at present is the implementation of legal protection for special facilities for female workers, which based on data from the Ministry of Health noted, in Indonesia there were 3041 companies, but only 152 companies accommodated the full provision of special facilities. Even though the number of companies that are aware of the rights of these facilities continues to increase from previous years, the figure is only $5 \%$ of all companies in Indonesia, although that does not mean that 2,889 companies do not fulfill the full rights of women workers but the rights contained Law No. $13 / 2003$ is only partially accommodated or replaced by compensation, even though this is not a justification, it still violates the provisions in Law No. 13/2003 concerning Labor and violates the provisions of the 1945 Constitution of the Republic of Indonesia.

Legal protection for the rights to special facilities is regulated in Article 76 paragraph (4) which states that female workers who work between 23:00 to 07.00 are entitled to nutritious food and beverage facilities and safeguarding decency and safety while at work. Related to security, the employers are also obliged to provide shuttle transportation for female workers between 23:00 to 5:00.

The provision of special facilities to female workers does not mean that women workers are more "special" than male workers but rather provides more protection to create security, comfort, and health for women workers in the workplace. It is clear that women is naturally different then men.

State Gazette of the Republic of Indonesia Year 2003 Number 39 Supplement to the State Gazette of the Republic of Indonesia Year 2003 Number 4279, hereinafter briefly Law Number 13 of 2003 concerning manpower provides women workers with the right to obtain special facilities listed in Article 76 Paragraph (1), (2), (3 ), and (4) Law Number 13 of 2003 with the aim of providing such special facilities can protect the physical, psychological, and reproductive of female workers, the rights of women workers, namely:[8]

1. Female workers/laborers under the age of 18 (eighteen) years are prohibited from being employed between 23:00 and 07:00.

2. Employers are prohibited from employing pregnant women workers/laborers who, according to doctor's information, are dangerous to the safety of the womb and their safety when working between 23:00 and 07:00.

3. Employers who employ female workers/laborers between 23:00 and 07:00 are required to:

a. Providing nutritious food and drinks.

b. Maintain decency and security while at work.

4. Employers are required to provide shuttle transportation for female workers/laborers who leave and return from work between 23:00 and 05.00.

The regulations on the pickup facility were strengthened by a ministerial decree in the Minister of Manpower and Transmigration Decree of the Republic of Indonesia Number Kep224/Men/2003 of 2003 concerning Obligations of Employers Employing Women Workers/Workers Between 23:00 to 07.00 ("Kepmenakertrans 224/2003 “). 
As an extension of Article 76 paragraph (4) of the Manpower Act, Kepmenakertrans $224 / 2003$ also confirms that employers are required to provide shuttle transportation for female workers/laborers who leave and return to work between 11:00 and 5:00 ie in Article 2 paragraph (2) which reads:

(2) "Employers are required to provide shuttle transportation for female workers/laborers who leave and return to work between 11:00 and 5:00."

In the Minister of Manpower and Transmigration 224/2003 also stipulated the technical aspects of shuttle transportation for women workers/laborers who leave and return from work between 23:00 and 05.00 with the technicalities:

a. Article 6 paragraph (1) Kepmenakertrans 224/2003:

"Employers are required to provide pickup starting from the pick-up place to work and vice versa."

b. Article 6 paragraph (2) Kepmenakertrans 224/2003:

"Pick-up is done from the pick-up place to work and vice versa between 23:00 to 05:00."

c. Article 7 paragraph (1) of the Minister of Manpower and Transmigration 224/2003: "Employers must establish pick-up and delivery locations in locations that are easily accessible and safe for women workers/laborers."

d. Article 7 paragraph (2) Kepmenakertrans 224/2003:

"The shuttle must be in a proper condition and must be registered with the company."

According to Article 76 paragraph (4) of the Manpower Law and Kepmentrans $224 / 2003$,it is clearly stipulated that employers must provide shuttle transportation for women workers/laborers who leave and return to work between 23:00 to 05:00. This is increasingly needed because of the rise of crime at night, this greatly affects the mentality of women workers and raises concerns when working at night especially the author's research site is a minimarket that operates for 24 hours making the place vulnerable to being the target of criminal acts such as theft, rape, even robbery and other criminal acts.

Related to the provision of feeding for female workers who work between 23:00 and 07:00. All companies that employ female workers during overtime have an obligation to provide food and drink that is at least 1,400 calories if the woman's workforce has worked overtime for 3 (three) hours or more. Feeding for female workers who work overtime is mandatory and not allowed to be replaced with any compensation as stipulated in Article 7 of the Minister of Manpower and Transmigration Decree No. KEP-102/MEN/VI/2004 of 2004 concerning Overtime Working Hours and Overtime Wages About the Obligations of Employers Who Employ Female Workers/Workers Between 23:00 to 07.00 which is an extension of Law Number 13 of 2003 concerning Manpower which further regulates the provision of food for female workers who work overtime between 23:00 to 07.00 which reads:[9]

Article 7 reads:

1) Companies that employ workers/laborers during overtime work are required to:

a) pay overtime wages;

b) provide opportunities for adequate rest; 
c) provide food and drinks of at least 1,400 calories if overtime is done for 3 (three) hours or more.

2) Provision of food and drink as referred to in paragraph (1) letter c may not be replaced with money.

Granting the right of transportation and providing food and drinks for female workers who work between 23:00 and 07:00 as stipulated in Law No. 13 of 2003 is a special facility which is a non-wage component so that these rights cannot be replaced by compensation. This is regulated in a Circular of the Minister of Manpower of the Republic of Indonesia Number SE-07/Men/1990 of 1990 concerning the Grouping of Wage Components and Non-Wage Income, which states that:[10]

"Facilities are pleasures in tangible/in-kind form provided by the company because of special matters or to improve workers' welfare, such as vehicle facilities (shuttle workers or others); free feeding; place of worship; babysitting; cooperative; canteen and others."

Security and decency guarantees for female workers are also facilities that must be fulfilled by companies for female workers as regulated in Article 76 Paragraph (3) letter (b) of Law Number. 13 of 2003 concerning manpower which reads: "Employers who employ female workers/laborers between 23:00 and 07:00 are required to maintain decency and security while at work". Because female workers are often targeted by sexual harassment in their workplaces both by coworkers and by employers.

This disorder can take the form of comments or verbal utterances, actions or physical contact that has sexual connotations. Although often by the person who is the target of the action, a disturbance does not seem to be directly endangering, but with that action which has an element of power and dominance, the person always becomes aware of his womanhood and virginity against the disorders.

The most extreme form of sexual harassment is rape, which is often very veiled, in the sense that it is often seen as an individual event and does not involve violations of human rights. Further provisions related to this matter are regulated in Article 5 of the Minister of Manpower and Transmigration 224/2003 which in guaranteeing the security and decency of women workers the company must provide:

a. provide security officers at work;

b. provide a proper bathroom/toilet with adequate lighting and is separate between female and male workers/laborers.

If the company does not accommodate the privileges of special pickup, provision of food and drink, as well as guarantees of security and decency, it will be fined according to article 76 paragraph (1), (2), (3), and (4) Law Number 13 of 2003 concerning Labor and through article 187 regulates sanctions which state:

(1) Whosoever violates the provisions referred to in Article 37 paragraph (2), Article 44 paragraph (1), Article 45 paragraph (1), Article 67 paragraph (1), Article 71 paragraph (2), Article 76, Article 78 Paragraph (2), Article 79 Paragraph (1), and Paragraph (2), Article 85 Paragraph (3), and Article 144 are liable to a maximum sentence of imprisonment of 1 (one) month and a maximum of 12 (twelve) months and/or a fine of at least IDR 10,000,000.00 (ten million rupiah) and a maximum of IDR 100,000,000 (one hundred million rupiah). 
The criminal act referred to in paragraph (1) constitutes a criminal offense.

Legal protection The right to special facilities furthermore is the right of babysitting and breastfeeding for female workers not explicitly regulated in Law Number 13 of 2003 concerning manpower, but in principle, the state provides legal protection for workers who are breastfeeding their children by pouring these rules into Article 83 of Law Number 13 of 2003 concerning Manpower reads:

"Female workers/workers whose children are still breastfeeding should be given the appropriate opportunity to breastfeed their children if it must be done during work time."

The rights for women and children have been regulated internationally under International Convention for Labor Organization No. 183 of 2000.[11] The article which states the special treatments for women at work is as follows:

Article 3 states:

"Each member, after consultation with representative employers 'and workers' organizations, takes appropriate steps to ensure that pregnant or breastfeeding women are not obliged to carry out work that has been determined by the competent authority to be detrimental to the health of the mother or child, or if the assessment has determined significant risk to the health of the mother or child."

Article 10 reads:

1) A woman must be given the right to one or more daily breaks or a reduction in daily work hours for breastfeeding her child.

2) Rest periods for breastfeeding or a reduction in daily work hours are allowed; the amount, duration of nursing breaks and procedures for reducing daily work hours must be determined by national law and practice. Rest or reduction of hours each working day will be counted as work time and paid accordingly.

Arrangements for special facilities for breastfeeding rooms for female workers are regulated in more depth in the Republic of Indonesia State Gazette of 2009 Number 144 concerning Health, hereinafter abbreviated to Law Number 36 of 2009 concerning Health Article 128 paragraph (2) which contains:[12]

1) Every baby has the right to get exclusive breast milk from birth for 6 (six) months, except for medical indications.

2) During breastfeeding, the family, the Government, local government and the community must fully support the baby's mother by providing special time and facilities.

3) Provision of special facilities as referred to in paragraph (2) shall be held in the workplace and public facilities.

This article regulates the special rights for women workers during breastfeeding, and wherein, the family, government, regional government and the community must fully support the mother by providing special time and facilities. Then, paragraph (3) mentions the provision of special facilities as referred to in paragraph (2) is held in the workplace and public facilities. If there is a party that violates Article 128 paragraph (2) of Law Number 36 
Year 2009 concerning Health, it will be subject to sanctions based on Article 200 which contains:

"Anyone who intentionally obstructs the exclusive breastfeeding program as referred to in Article 128 paragraph (2) shall be sentenced to a maximum of 1 (one) year imprisonment and a maximum fine of IDR. 100,000,000.00 (one hundred million rupiah)."

\subsection{Implement legal protection for special facility rights at Alfamart KP Rambutan}

Law Number 13 of 2003 concerning Manpower which is interrupted by one of the law enforcers from problems related to the protection of workers and employers as well as the protection of the rights and obligations of each party. Labor protection in Indonesia is regulated in Law Number 13 of 2003 concerning Manpower starting from Article 67 to Article 101 which covers the protection of workers with disabilities, child labor, female labor, working time, worker safety and health, wages and welfare the worker. Worker protection aims to guarantee the basic rights of workers, opportunities, and treatment without discrimination. The essence of the formation of Law No. 13 on Manpower is none other than realizing the welfare of workers who are expected to be able to provide progress in the Indonesian business world, but the writer here finds the inability of Law No. 13 of 2003 concerning manpower to work effectively in its function as protective rights for special facilities for female workers.

In reality, there are many complaints from female workers regarding the regulation being not implemented optimally, such as complaints from the female workers that are not given the opportunity to receive additional education at the expense of the company. The female worker is considered single so that she does not get family benefits despite the fact that she is married and has children, and there are no facilities that can support the comfort and safety of female workers even though special facilities are non-wage components so that fulfillment is mandatory and those rights are cannot be replaced with compensation.

To find out about the special facilities for picking up female workers who work at night PT. Alfamart, the writer conducted an interview with one of the parties from PT. Alfamart namely Policy Holders namely manager of PT. Alfamart, as well as several female workers who work at night who work at Alfamart outlets around Kampung Rambutan, East Jakarta.

Based on observations on Alfamart working hours starting from 07.00 to 07.00 (nonstop), which are divided into 3 (three) Shift working hours, namely: (i) Shift 1 (first) from 07.00 to 16.00, (ii) Shift 2 ( two) from 14.00 to 23.00 , and (iii) Shift 3 (three) from 22.00 to 07.00.

Considering the 24-hour work period will certainly affect the safety and health of women workers, Alfamart's employers must provide protection related to legal provisions and special facilities for female workers because the company employs female workers at night. But in reality, the legal provisions against women workers are not fully implemented.

Legal provisions for women workers at night based on law number 13 of 2003 concerning employment in Article 76 paragraph (1) stipulates that:

"Female workers/workers aged less than 18 (eighteen) years are prohibited from being employed between 23:00 and 07:00."

Based on these provisions, Alfamart is not allowed to employ workers under the age of 18 years. In an interview with $\mathrm{Mr} \mathrm{X}$ as Alfamart Manager he said "the absolute requirement to be 
an employee of Alfamart is at least a high school graduate. Not employing workers under the age of 18 (eighteen) in Alfamart, this already applies throughout Indonesia “.

According to the interview to Mr. X was also found that pregnant female workers were allowed to take leave on condition that they report to their superiors accompanied by a doctor's statement. However, after being healthy, the worker must change his working hours as long as he is not working due to illness/pregnancy so that it is also in accordance with article 76 paragraph (2) of Law Number 13 of 2003 which reads:

"Employers are prohibited from employing pregnant women workers/laborers who, according to the doctor's statement, are dangerous to the health and safety of their womb and themselves when working between 23:00 and 07:00."

Seen above Alfamart company has fulfilled some of the rights of women workers, but the problem is the granting of special facilities rights in article 76 paragraph (3) which reads:

"Employers who employ female workers or laborers between 11:00 and 7:00 are required to:

(a) Providing nutritious food and drinks."

The fact that happened in Alfamart, as the results of an interview with Mr. X found that during this time female workers who worked overtime were never given food or drink while we worked between 22:00 to 07.00. Even women workers were not given any compensation other than overtime wages. Then based on the results of an interview from Silvia who is the cashier Alfamart Silvia said that she was never given food when working late at night. If workers wanted to eat, then they would buy their own. Based on this, it indicates that Alfamart does not fulfill the right to health insurance for female workers and therefore not following Law No. 13 of 2003 concerning Manpower Article 76 Paragraph (3) Giving an appropriate foods and drinks at night important for women workers because night is a time to rest. Thus the Alfamart company should provide food and drinks to women workers at night as health insurance for their work, this is to support the improvement of the company's operations and the safety of its workers.

This provision has not been implemented by the company because it has not been regulated in the regulation book in Alfamart company and work agreements related to providing nutritious food and drinks to workers while working in the shop. So, it could be said that Alfamart only paid more attention to the safety and security problems of workers while at work without paying more attention to the physical, psychological and reproductive health of their female workers.

Related to the regulation regarding the company's obligation to provide shuttle transportation for women workers/laborers who leave and return to work between 23:00 and 05.00 as referred to in Article 76 paragraph (4) which reads:

"Employers must provide shuttle transportation for women workers/laborers who leave and return from work between 23:00 and 05.00."

The writer once again found a mismatch between the aspirations (Das Sein) and what actually happened (Das Solen) where based on Mr. X's interview he said that, "It does not accommodate the pick-up of female workers who work between 23:00 and 07:00."

Silvia's interview which said that: 
"He was never escorted or picked up by Alfamart and was indeed not provided so going home on his own motorbike usually somewhat increases his sense of security going and going home to work by being picked up by friends who work on the same work shift."

Regarding the safety and safety of workers, Mr. X said that in supporting the safety of women workers who had to leave and go home at night Alfamart placed workers in a shop close to the domicile of the worker, however, if you see the provisions in Law No.13 of 2003 there is no one even the articles that justify what Alfamart did.

Thus, it can be seen that Alfamart has not accommodated the rights that should be given to female workers, this is because Alfamart considers that the company is only responsible to workers while in the workplace itself, while outside the workplace is no longer the responsibility of the company but the responsibilities of each worker. So in this case it cannot be denied that when workers leave and return from work, their safety is not guaranteed. This is because it is not borne by the company that should be obliged to be given to women who work at night for their safety while traveling to and from work with the hope of surviving to their destination.

Related to maintaining decency and safety while at work. The legal provisions for female workers in terms of safeguarding decency and security while at work, based on the results of an interview with Silvia that already feels safe when working overtime because they feel cared for by their friends and there is CCTV which indeed adds a sense of security when working. Then Mr. X added:

"Workers at Alfa Mart both female and male workers, and during the day or night will be protected by Alfamart company. Because of this the workers have become a responsibility for the company to provide guarantees of safety and security as long as they work in Alfamart stores by hiring security from nearby organizations or providing people to arrange parking while maintaining security and also the store is equipped with CCTV. In addition, for workers who are still working hours and have an accident will be borne by the company by providing insurance and BPJS to workers."

However, this has not been said to have fulfilled the legal provisions related to the safeguarding of decency and security for workers while at work. Because in direct observation by the author, it was found that the bathrooms available at Alfamart were not separated between men and women and reinforced by what was said by Mr. X that, "The booth provides a bathroom but does not seem to separate bathrooms for men and women. "This sounds trivial but this turns out to be important in order to maintain the decency of female workers because it clearly protects the privacy and security of female workers from sexual harassment of the opposite sex.

Related to fulfilling the right to breastfeeding facilities, from the direct observation of the author and interviews with several female Alfamart workers, it was found that there is no special room for nursing mothers provided as the author's vision of the room in Alfamart is only 3 parts namely warehouse, bathroom, and shop. In the interview, Mr. X answered, "no special room for breastfeeding is provided, usually there is only a rest room that is shared," this is not in accordance with what is regulated in Article 83 of Law Number 13 of 2003 regarding Manpower and Law Number 36 Year 2009 Concerning Health Article 128 paragraph (2) which reads: 
Article 83 of Law No. 13 of 2003 reads:

"Female workers/workers whose children are still breastfeeding should be given the appropriate opportunity to breastfeed their children if it must be done during work time."

Article 128 paragraph (2) of Law Number 36 Year 2009 reads:

1) Every baby has the right to get exclusive breast milk from birth for 6 (six) months, except for medical indications.

2) During breastfeeding, the family, the Government, local government and the community must fully support the baby's mother by providing special time and facilities.

3) Provision of special facilities as referred to in paragraph (2) shall be held in the workplace and public facilities.

Which automatically also violates what is in the article related to breastfeeding workers' rights, namely article 3 and article 10 of the International Labor Organization (ILO) Convention No. 183 of 2000 concerning Protection of Maternity:

Article 3 reads:

"Each member, after consultation with representative employers 'and workers' organizations, takes appropriate steps to ensure that pregnant or breastfeeding women are not obliged to carry out work that has been determined by the competent authority to be detrimental to the health of the mother or child, or if the assessment has determined significant risk to the health of the mother or child."

Article 10 reads:

1) A woman must be entitled to one or more daily breaks or a reduction in daily work hours for breastfeeding her child.

2) Rest periods for breastfeeding or a reduction in daily work hours are allowed; the amount, duration of nursing breaks and procedures for reducing daily work hours must be determined by national law and practice. Rest or reduction of hours each working day will be counted as work time and paid accordingly.

This is considered important because it provides a guarantee of the safety and comfort of women workers and infants who still need breast milk if this is not fulfilled, immoral treatment can occur to nursing mothers who will later affect the performance of these female workers.

From the discussion above, data have been found that show that the work of immoral care and security in the workplace for female workers by Alfamart companies has not been optimal, bearing in mind this is important with the intention that workers feel comfortable in carrying out their respective duties.

Based on the theory of law enforcement in the Chambliss and Seidman communities, it is argued that the effectiveness of a law is seen from the regulatory body, the law enforcement agency, and the role holders, related to the implementation of special facility rights protection in Law Number. 13 of 2003 is arguably not running optimally.

In assessing the effectiveness of the application of law, especially laws and regulations, there are various ways in which one of the ways is by discussing the law in its sense as a tool to change society or Social-Engineering (social engineering). it is in accordance with the ideas 
to be realized by the law itself. In an effort to ensure the realization of the legal function as a better engineered society, not only law is needed and implemented, but also guaranteeing the realization of these legal norms into legal practice, or in other words, guaranteeing law enforcement (law enforcement) is good. In terms of law as a tool to change society, positioning humans as a very important factor in the study of the law. So in this case it is appropriate when implementing the theory of the influence of social forces in the operation of law in society by Chambliss and Seidman, the theory places 3 (three) components as the main supporters of the operation of law in society, which includes:

1. Regulatory Institutions

2. Regulatory Application Institutions

3. Role Holder

Of the three basic components Chambliss and Seidman propose the following argument:

1. Every legal regulation tells how a Role Occupant is expected to act

2. How a person in charge will respond to the rule of law which is a function of the rules directed at him, sanctions, the activities of the institution and the whole complex of social, political, and other forces.

3. How the implementing institutions act in response to the rule of law, the function of the rule of law aimed at them, their sanctions, the whole complex of social, political and other forces concerning themselves and feedback from the stakeholders.

4. How legislators will act is a function of the rules governing their behavior, sanctions, the whole complex of social, political, ideological, and other forces concerning themselves and the feedback that comes from the holders of bureaucratic participation.[13]

If viewed from the theory above, the effectiveness of the legal protection of the special facilities for women workers which is regulated in Law Number 13 of 2003 concerning Manpower is considered not optimal because Law Number 13 of 2003 concerning Labor only fulfills 1 (one) element, namely the manufacturing body legal regulations. The legal protection provisions for special facilities for women workers in Law Number 13 of 2003 concerning Manpower have regulated what must be done by the role holders as well as implementing institutions for regulations in the Act accompanied by implementing regulations and others. But this is still lacking, this is due to the two other elements making the arrangement not considered optimal in its application. What makes this arrangement not optimal is the elements of the implementing agency and its role holders who are not doing what should be done as Law Number 13 of 2003 concerning Labor.

However, if we associate with law-making institutions the legal substance requirements can already convey how the role holders should provide legal protection for special facility rights clearly stipulated in Law 13 of 2003 concerning manpower where facilities for female workers who work late night in the form of pickup, provision of food, as well as guarantees of guarding decency and security for women workers who work at night have been regulated in article 76 of Law Number. 13 of 2003 concerning employment. Then related to the fulfillment of special facilities for breastfeeding room has been regulated in Article 83 of Law Number 13 of 2003 concerning Labor and Law Number 36 of 2009 concerning Health Article 128 paragraph (2). And also Law Number 13 of 2003 concerning manpower and implementing regulations has accommodated what must be done by law enforcement agencies in carrying out supervision related to fulfilling the rights of the special facility. However, what has been regulated in Law Number 13 of 2003 concerning Manpower is not heeded by the role holders 
and existing legal implementation institutions so that it makes Law Number. 13 of 2003 in the regulation concerning the protection of the rights to special facilities for female workers is considered less effective.

\section{Conclusion}

Based on the description above, it can be concluded that there are two forms of protection of special facility rights for women workers according to the Law Number 13 of 2003 concerning Labor. First, the right to get special facilities for female workers who work late at night, such as pickup and feeding facilities. Secondly, security and decency guarantees as stated in Article 76 Paragraph (3) of Law Number 13 of 2003. The second special facility right is a nursing room facility has been regulated in article 83 of Law Number 13 of 2003 concerning Labor. The implementation of legal protection for the special facilities for women workers at Alfamart Kampung Rambutan has not run optimally due to the lack of perceived role of the supervisory and cultural hierarchy to put men is superior than women. 


\section{References}

[1] T. B. Aji, "Tenaga kerja wanita (studi tentang perlindungan hukum menurut undangundang nomor 13 tahun 2003 tentang ketenagakerjaan di Pt. Adetex Boyolali)," Universitas Muhammadiyah Surakarta, 2010.

[2] J. G. Mambu, "Aspek Perlindungan Hukum terhadap Pekerja Wanita (Menurut Undang-undang Nomor. 13 Tahun 2003)," Jure J. Huk. dan Syar'iah, vol. 2, no. 2, pp. 150-161, 2010.

[3] S. Susiana, "Pelindungan Hak Pekerja Perempuan dalam Perspektif Feminisme," J. Aspir., vol. 8, no. 2, pp. 207-221, 2019.

[4] S. Kusumaningtyas, "95 Persen Perusahaan di Indonesia Belum Penuhi Hak Pekerja Perempuan," $20 \quad$ Apr 2018. [Online]. Available: https://sains.kompas.com/read/2018/04/20/203600423/95-persen-perusahaan-diindonesia-belum-penuhi-hak-pekerja-perempuan. [Accessed: 05-Mar-2019].

[5] G. Suteki, and Taufani, Metodologi Penelitian Hukum: Filsafat, Teori Dan Praktik. Jakarta: Raja Grafindo Persada, 2018.

[6] Law Number 13 of 2003 concerning Manpower. .

[7] E. S. Salim HS., and Nurbani, Penerapan Teori Hukum Pada Penelitian Tesis dan Disertasi. Jakarta: Raja Grafindo Persada, 2013.

[8] State Gazette of the Republic of Indonesia Year 2003 Number 39 Supplement to the State Gazette of the Republic of Indonesia Year 2003 Number 4279, hereinafter briefly Act Number 13 of 2003 concerning manpower. .

[9] Decree of the Minister of Manpower and Transmigration No. KEP-102/MEN/VI/2004 of 2004 concerning Overtime Working Hours and Overtime Work Wages. .

[10] Circular of the Minister of Manpower of the Republic of Indonesia Number SE07/Men/1990 of 1990 concerning Grouping of Wage Components and Non-Wage Income.

[11] International Labor Organization (ILO) Convention Number 183 of 2000. .

[12] Law Number 36 of 2009 concerning Health. .

[13] S. Rahardjo, Hukum dan Masyarakat. Bandung: Angkasa, 1980. 